Abstract

\title{
Early Structural Changes of Constructed Soils in Bioretention Bed for Stormwater Infiltration ${ }^{+}$
}

\author{
Michal Snehota ${ }^{1, *}$, Petra Heckova ${ }^{2}$ and John Koestel ${ }^{3}$ \\ 1 Faculty of Civil Engineering, Czech Technical University in Prague, 16629 Prague, Czech Republic \\ 2 University Centre for Energy Efficient Buildings, Czech Technical University in Prague, \\ 27343 Bustehrad, Czech Republic; heckopet@cvut.cz \\ 3 Department of Soil and Environment, Swedish University of Agricultural Sciences, \\ 750 07Uppsala, Sweden; John.Koestel@slu.se \\ * Correspondence: michal.snehota@cvut.cz \\ † Presented at TERRAenVISION 2019, Barcelona, Spain, 2-7 September 2019. \\ Published: 16 June 2020
}

\begin{abstract}
Properties of constructed soils determine the functioning of nature-based solutions, such as stormwater bioretention beds. Water infiltration, colloid transport and heat transport in the soil layer are affected by changes in pore system geometry of the biofilter layer particularly due to the development of macropores and by clogging of pores by particles. The rate of alterations is often faster than in natural soils due to higher loads of particles as well due to frequent variations of the water content. In the presented study we assess the temporal changes of soil structure of biofilter layer of the experimental bioretention beds by conducting field-scale experiments and noninvasive diagnostics of soil cores. The aim is to relate changes in bioretention cell performance to the structural changes of biofilter soil. Two identical experimental bioretention cells were constructed in December 2017. The first bioretention cell collects the stormwater from the roof of the nearby experimental building (roof area $38 \mathrm{~m}^{2}$ ). The second bioretention cell is supplied from a tank using a controlled pump system, which allows generating of artificial rainfall-runoff episodes. The bioretention were planted in July 2018 by four perennial plants (Aster novae-angliae "Purple Dome"; Hemerocallis 'Lemon Bells'; Euphorbia amygdaloides; Molinia caerulea). Bioretention cells are instrumented with water content probes, tensiometers, water potential meters. Outflow from the bioretention cell is monitored by tipping buckets. Small undisturbed samples were collected from the biofilter layer before and after the first vegetation season and examined by $\mathrm{X}$-ray micro computed tomography (CT). Image analysis involved segmentation of the macropore network and calculation of the properties of the pore system. The analysis of X-ray CT imaging demonstrates the significant decrease of macroporosity during the first vegetation season. The outcomes of the research will lead to improved design and management procedures for and bioretention beds.
\end{abstract}

Keywords: bioretention; macropores; X-ray tomography; constructed soil; infiltration

(C) 2020 by the authors. Licensee MDPI, Basel, Switzerland. This article is an open access article distributed under the terms and conditions of the Creative Commons Attribution (CC BY) license (http://creativecommons.org/licenses/by/4.0/). 